Proc. of the International Conference on Mechanochemistry and Mechanical Alloying, Kraków, Poland, June 22-26, 2014

\title{
The Influence of Chemical Modification by Silver on Hydrogen Storage Properties of Nanocrystalline $\mathrm{Ti}_{2} \mathrm{Ni}$ Alloy
}

\author{
M. BALCERZAK*AND M. JURCZYK \\ Institute of Materials Science and Engineering, Poznań University of Technology, \\ pl. M. Skłodowskiej-Curie 5, 60-965 Poznań, Poland
}

\begin{abstract}
In this study mechanical alloying process with subsequent annealing at $750{ }^{\circ} \mathrm{C}$ for $0.5 \mathrm{~h}$ were used to produce $\mathrm{Ti}_{2} \mathrm{Ni}$-based nanocrystalline alloys and composite. To improve electrochemical properties, Ti-Ni-based alloy was chemically modified by $5 \mathrm{wt} \%$ of silver powder. X-ray diffraction analyses showed formation of nanocrystalline $\mathrm{Ti}_{2} \mathrm{Ni}$ main phase. Electrochemical studies revealed a positive effect of chemical modification by silver on $\mathrm{Ti}_{2} \mathrm{Ni}$ alloy. All synthesized materials were used as negative electrodes for $\mathrm{Ni}-\mathrm{MH}_{x}$ batteries. The highest discharge capacity equaled $303 \mathrm{mAh} / \mathrm{g}$, at $40 \mathrm{~mA} / \mathrm{g}$ discharge current. All electrochemical measurements were done in $6 \mathrm{M}$ $\mathrm{KOH}$ solution.
\end{abstract}

DOI: 10.12693 /APhysPolA.126.892

PACS: 82.47.Cb, 88.30.rd

\section{Introduction}

$\mathrm{Ti}_{2} \mathrm{Ni}$ alloy have been recently examined for negative electrode in $\mathrm{Ni}^{-} \mathrm{MH}_{x}$ batteries. Theoretical electrochemical capacity of $\mathrm{Ti}_{2} \mathrm{Ni}$ hydride equals $500 \mathrm{mAh} / \mathrm{g}$ [1]. First experimental studies on this alloys were performed by Luan et al. [2-4]. In this works arc melting was used to obtain this alloy. The highest discharge capacity obtained by mentioned group was just $160 \mathrm{mAh} / \mathrm{g}$ which was caused by accumulation of irreversible metal hydride.

Electrochemical properties can be improved by changing size of alloy crystals. Mechanical alloying (MA) is novel method for production of nanocrystalline hydrogen storage materials. This process which consists of repeated fracturing, mixing and cold welding provides formation of new nanostructured, non-equilibrium alloys [5]. In our previous work we studied $\mathrm{Ti}_{2} \mathrm{Ni}$ alloy produced by MA process. Maximum discharge capacity for this system was $253 \mathrm{mAh} / \mathrm{g}$. This improvement of electrochemical properties was due to creation of new clean surfaces, greater specific surface area and reduction in powder size [6].

Another way to improve mentioned properties is chemical modification of alloys for Ni-MH${ }_{x}$ batteries. Elemental substitution of Ni by other metallic or non-metallic elements can improve cycle stability and decrease metal hydride stability [7-10]. Silver is one of element which is used for chemical modification of hydrogen storage materials [11, 12].

In this paper which is a continuation of our previous work, structure, agglomerate size and morphology, corrosion and electrochemical properties in $6 \mathrm{M} \mathrm{KOH}$ were measured. To the best of our knowledge, there are no

\footnotetext{
${ }^{*}$ corresponding author; e-mail:

mateusz.balcerzak@put.poznan.pl
}

reports on chemical modification of $\mathrm{Ti}_{2} \mathrm{Ni}$ alloy by $\mathrm{Ag}$ element in order to improve electrochemical properties of electrode for $\mathrm{Ni}-\mathrm{MH}_{x}$ batteries.

\section{Experimental details}

MA process was used to produce all of studied materials. In our work SPEX 8000 Mixer Mills were used. All synthesis and handlings were done in an argon atmosphere. Every powder milling lasted $8 \mathrm{~h}$. Ti, Ni, and $\mathrm{Ag}$ powders which were used in our work had at least $99.9 \%$ purity.

Detailed description of synthesis procedure was described in our previous works [6, 13]. In this work two materials were synthesized. First one was pure $\mathrm{Ti}_{2} \mathrm{Ni}$ alloy and the second one was chemically modified $\mathrm{Ti}_{2} \mathrm{Ni}$ alloy with $5 \mathrm{wt} \%$ of $\mathrm{Ag}$ added to elemental powder mixture before MA. As a result of $8 \mathrm{~h}$ MA amorphous materials were obtained $[6,13]$. In order to obtain $\mathrm{Ti}_{2} \mathrm{Ni}^{-}$ type structure MA powders were annealed in argon atmosphere at $750{ }^{\circ} \mathrm{C}$ for $0.5 \mathrm{~h}$. Additionally $\mathrm{Ti}_{2} \mathrm{Ni}$-based composite was produced by 5 min milling of $\mathrm{MA}$ and annealed $\mathrm{Ti}_{2} \mathrm{Ni}$ alloy with $5 \mathrm{wt} \%$ of $\mathrm{Ag}$.

To facilitate the reading of work, obtained materials were labeled as follows:

- $\mathrm{Ti}_{2} \mathrm{Ni}$ alloy without changes is labeled as $\mathrm{Ti}_{2} \mathrm{Ni}$,

- $\mathrm{Ti}_{2} \mathrm{Ni}$ with 5 wt\% of $\mathrm{Ag}$ nanocrystalline alloy is labeled as $\mathrm{Ti}_{2} \mathrm{Ni}+\mathrm{Ag}$,

- Composite of $\mathrm{Ti}_{2} \mathrm{Ni}$ alloy with 5 wt\% of Ag elemental powder is labeled as $\mathrm{Ti}_{2} \mathrm{Ni}+(\mathrm{Ag})$.

X-ray diffraction (XRD) and scanning electron microscopy (SEM) was used to study structure, microstructure, and morphology of obtained materials. Based on XRD data average crystallite size were calculated using the Scherrer equation. SEM pictures were used to made particle size dimension distribution histograms. 
Corrosion resistance behavior was examined during potentiodynamic tests. Measurements were made in $6 \mathrm{M}$ $\mathrm{KOH}$ solution. Scanning range was from -1.5 to $1 \mathrm{~V}$. Scanning speed equaled $1 \mathrm{mV} / \mathrm{s}$.

Obtained materials in mixture with $10 \mathrm{wt} \%$ of Ni powder were used as negative electrodes in $\mathrm{Ni}-\mathrm{MH}_{x}$ systems (electrochemical measurements). This mixtures were cold pressed under $800 \mathrm{MPa}$ to form pellets. Electrodes were charged and discharged at $40 \mathrm{MA} / \mathrm{g}$. A cut-off potential vs. $\mathrm{Hg} / \mathrm{HgO} / 6 \mathrm{M} \mathrm{KOH}$ was $-0.7 \mathrm{~V}$. All electrochemical measurements were performed in $6 \mathrm{M} \mathrm{KOH}$ solution. Cycle stability of materials was evaluated by capacity retaining rate after 18 th cycle

$$
R_{h}=\frac{C_{18}}{C_{\max }} \times 100 \%,
$$

where $\mathrm{C}_{18}$ and $\mathrm{C}_{\max }$ are discharge capacities at the 18th cycle and maximum discharge capacity, respectively. Description of activation procedure and electrochemical measurements were described in our previous papers $[6,13]$.

\section{Results and discussions}

$\mathrm{Ti}_{2} \mathrm{Ni}$-based materials were characterized by XRD, SEM, corrosion and electrochemical measurements. Addition of $\mathrm{Ag}$ to mixture of elemental powders did not affect MA process (not shown here). After MA process, amorphous powders were heat treated at $750^{\circ} \mathrm{C}$ for $0.5 \mathrm{~h}$. Figure 1 shows XRD spectra of annealed materials.

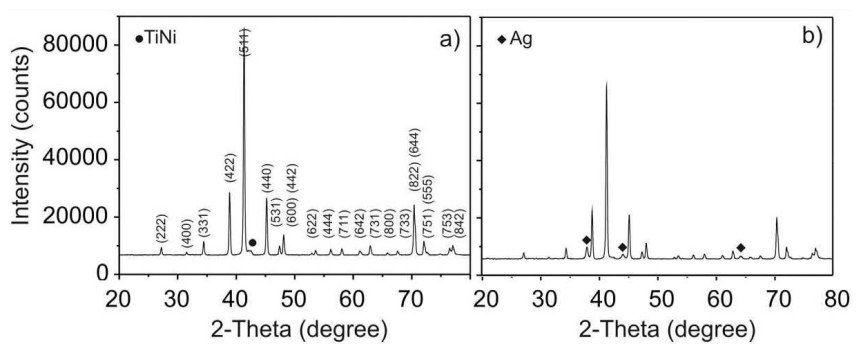

Fig. 1. XRD spectra of annealed powders of: (a) $\mathrm{Ti}_{2} \mathrm{Ni}$ alloy, (b) $\mathrm{Ti}_{2} \mathrm{Ni}+\mathrm{Ag}$.

Almost all of peaks are related to presence of $\mathrm{Ti}_{2} \mathrm{Ni}$ phase. Small amount of minor phase was also detected: hexagonal TiNi. Small peaks related to presence of Ag crystals are visible on $\mathrm{Ti}_{2} \mathrm{Ni}+\mathrm{Ag}$ alloy and $\mathrm{Ti}_{2} \mathrm{Ni}+(\mathrm{Ag})$ composite (not shown here) XRD patterns. Intensity of $\mathrm{Ag}$ peaks was much higher for composite material. Comparing both patterns of materials which had the same amount of silver, we think that most of silver in $\mathrm{Ti}_{2} \mathrm{Ni}+\mathrm{Ag}$ alloy reacted with Ti and Ni creating Ti-Ni based phase. Small part of $\mathrm{Ag}$ did not react with other elements - residue is visible on XRD spectra (Fig. 1a). Based on XRD date, average crystalline size were calculated using the Scherrer equation. Silver addition does not affect the average crystallite size of alloy. For unmodified and modified alloy it equaled 32 and $31 \mathrm{~nm}$, respectively (Table I).

SEM pictures of $\mathrm{Ti}_{2} \mathrm{Ni}$ and $\mathrm{Ti}_{2} \mathrm{Ni}+\mathrm{Ag}$ alloys are shown in Fig. 2. Both of them had crystallite agglomerates in
TABLE I

Crystallites size and average particle size of $\mathrm{Ti}_{2} \mathrm{Ni}$ based materials.

\begin{tabular}{c|c|c}
\hline \hline Composition & $\begin{array}{c}\text { Crystallites size } \\
\text { ofnealed powders } \\
{[\mathrm{nm}]}\end{array}$ & $\begin{array}{c}\text { Average agglomerates } \\
\text { size of annealed powders } \\
{[\mu \mathrm{m}]}\end{array}$ \\
\hline $\mathrm{Ti}_{2} \mathrm{Ni}$ & 32 & 45.3 \\
$\mathrm{Ti}_{2} \mathrm{Ni}+\mathrm{Ag}$ & 31 & 49.6
\end{tabular}

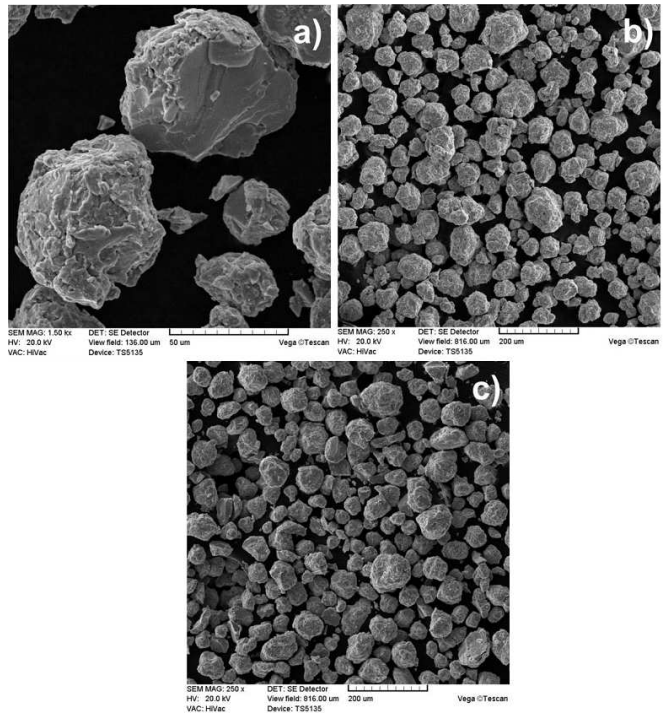

Fig. 2. SEM picture of $\mathrm{Ti}_{2} \mathrm{Ni}(\mathrm{a}, \mathrm{b})$ and $\mathrm{Ti}_{2} \mathrm{Ni}+\mathrm{Ag}(\mathrm{c})$.

size from a few to one $150 \mu \mathrm{m}$. Materials after MA and additional annealing had cleavage fracture morphology (Fig. 2a). Based on SEM pictures particle size dimension distribution histograms were made (Fig. 3). Most of

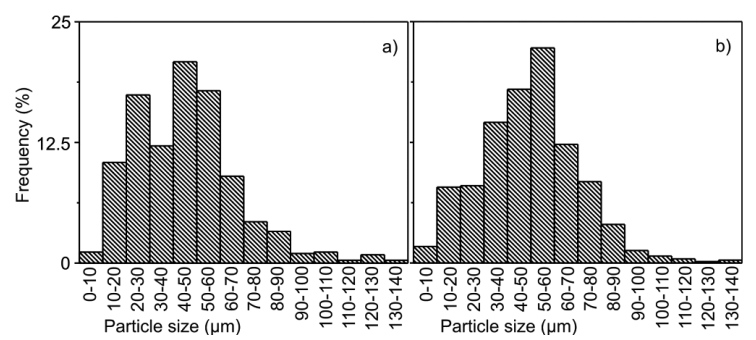

Fig. 3. Particle size dimension distribution histograms of: (a) $\mathrm{Ti}_{2} \mathrm{Ni}$, (b) $\mathrm{Ti}_{2} \mathrm{Ni}+\mathrm{Ag}$.

agglomerates had size less than $100 \mu \mathrm{m}$. Average size of agglomerates is similar for $\mathrm{Ti}_{2} \mathrm{Ni}$ and $\mathrm{Ti}_{2} \mathrm{Ni}+\mathrm{Ag}$ alloys. It equaled less than $50 \mu \mathrm{m}$ (Table I). Particle size dimension distribution histogram of $\mathrm{Ti}_{2} \mathrm{Ni}+\mathrm{Ag}$ seems to be more uniform. Figure 4 shows potentiodynamic polarization curves of the uncharged studied alloys and composite. All curves have a very similar shape. Initially occurring area of resistance is followed by active dissolution of formed hydroxide layer. Subsequently passivation process was observed. During this process the hydroxide layer is rapidly formed. In case of $\mathrm{Ti}_{2} \mathrm{Ni}$ and $\mathrm{Ti}_{2} \mathrm{Ni}+\mathrm{Ag}$ 


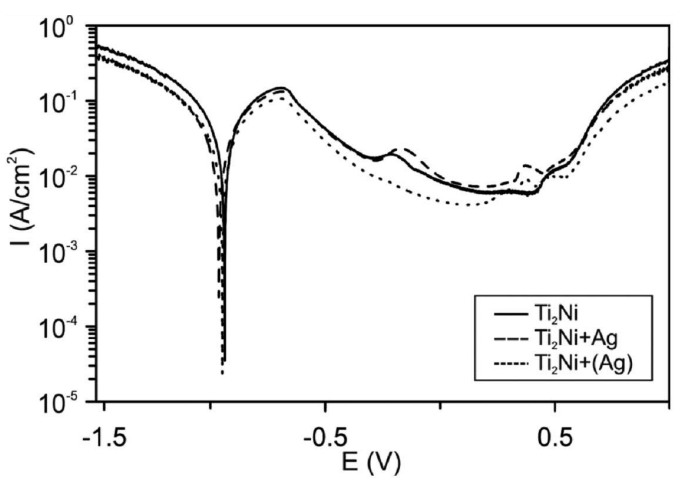

Fig. 4. Potentiodynamic curves of $\mathrm{Ti}_{2} \mathrm{Ni}$-based materials in $6 \mathrm{M} \mathrm{KOH}$ solution.

TABLE II

Maximum discharge capacity, capacity retaining rate after 18th cycle, corrosion current of $\mathrm{Ti}_{2} \mathrm{Ni}$-based materials.

\begin{tabular}{c|c|c|c}
\hline \hline Composition & $\begin{array}{c}\text { Max. discharge } \\
\text { capacity } \\
{[\mathrm{mAh} / \mathrm{g}]}\end{array}$ & $\begin{array}{c}\text { Capacity retain- } \\
\text { ing rate after } \\
18^{\text {th }} \text { cycle }[\%]\end{array}$ & $\begin{array}{c}\text { Corrosion } \\
\text { current } \\
{\left[\mathrm{A} / \mathrm{cm}^{2}\right]}\end{array}$ \\
\hline $\mathrm{Ti}_{2} \mathrm{Ni}$ & 256 & 31 & $1.15 \times 10^{-2}$ \\
$\mathrm{Ti}_{2} \mathrm{Ni}+\mathrm{Ag}$ & 294 & 14 & $1.25 \times 10^{-2}$ \\
$\mathrm{Ti}_{2} \mathrm{Ni}+(\mathrm{Ag})$ & 303 & 13 & $0.72 \times 10^{-2}$
\end{tabular}

the hydroxidation process was disturbed for some reason which resulted in a creation of new clean surface. The surface was then quickly hydroxidized to reach the passive state. This situation was not observed for studied composite where passivation process proceeded continuously. Corrosion current of all measured materials is summarized in Table II. Ag element in $\mathrm{Ti}_{2} \mathrm{Ni}$ alloy and composite improved the corrosion resistance of materials in $6 \mathrm{M} \mathrm{KOH}$ solution. The best corrosion resistance was obtained for $\mathrm{Ti}_{2} \mathrm{Ni}+(\mathrm{Ag})$ composite. Observed slight improvement of corrosion properties may be caused by suppressed pulverization of electrode due to the anticorrosion effect of silver addition.

Electrochemical properties of materials are shown and summarized in Fig. 5 and in Table II. The best activation

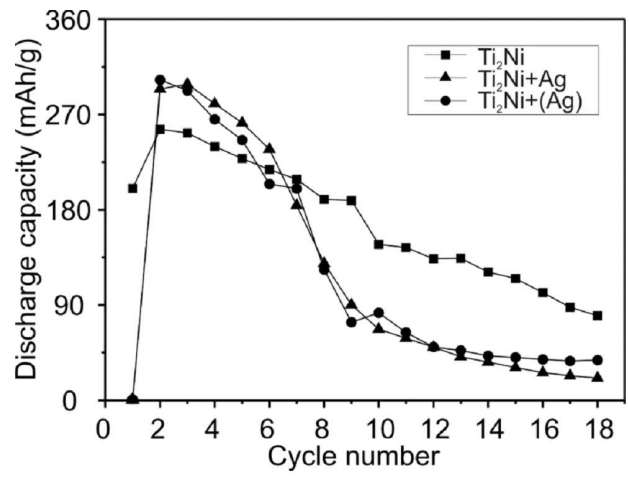

Fig. 5. Discharge capacities as a function of cycle number of electrode prepared with $\mathrm{Ti}_{2} \mathrm{Ni}$-based materials (solution $6 \mathrm{M} \mathrm{KOH}$, room temperature). properties had $\mathrm{Ti}_{2} \mathrm{Ni}$ alloy. Both materials with $\mathrm{Ag}$ in their composition showed almost zero discharge capacity in first charge/discharge cycle. The maximum discharge capacity of studied alloys and composite was obtained in 2nd or 3rd cycle. The highest discharge capacity showed $\mathrm{Ti}_{2} \mathrm{Ni}+(\mathrm{Ag})$ alloy $-303 \mathrm{mAh} / \mathrm{g}$. However both $\mathrm{Ti}-\mathrm{Ni}-$ $\mathrm{Ag}$ materials had much higher maximum discharge capacity. Decrease of discharge capacity during cycles was observed for all of materials. This situation can be due to formation of oxides, hydroxides and irreversible hydride phases. The mentioned decrease of discharge capacity is much bigger for $\mathrm{Ti}_{2} \mathrm{Ni}+\mathrm{Ag}$ alloy and for $\mathrm{Ti}_{2} \mathrm{Ni}+(\mathrm{Ag})$ composite than for unmodified $\mathrm{Ti}_{2} \mathrm{Ni}$ alloy. The best capacity retaining rate was obtained for $\mathrm{Ti}_{2} \mathrm{Ni}$ material $31 \%$ after 18 th cycles.

\section{Conclusions}

$\mathrm{Ti}_{2} \mathrm{Ni}$-based alloys and composites with $\mathrm{Ag}$ were used as negative electrodes for $\mathrm{Ni}-\mathrm{MH}_{x}$ rechargeable batteries. Based on this study the following conclusions can be obtained:

- Chemical modification of $\mathrm{Ti}_{2} \mathrm{Ni}$ alloy by $5 \mathrm{wt} \%$ of Ag element did not affect crystallite size and average agglomerate size.

- Ag particles improves corrosion resistance of $\mathrm{Ti}_{2} \mathrm{Ni}$ alloy in alkaline solution.

- $\mathrm{Ti}_{2} \mathrm{Ni}$ with 5 wt\% composite had the highest electrochemical discharge capacity which equaled $303 \mathrm{mAh} / \mathrm{g}$.

References

[1] H. Buchner, M.A. Gutjahr, K.D. Beccu, H. Saufferer, Z. Metalkd. 63, 497 (1972).

[2] B. Luan, H.J. Zhao, H.K. Liu, S.X. Dou, J. Power Sources 62, 75 (1996).

[3] B. Luan, H.K. Liu, S.X. Dou, J. Mater. Sci. 32, 2629 (1997).

[4] B. Luan, S.J. Kennedy, H.K. Liu, S.X. Dou, J. Alloys Comp. 267, 224 (1998).

[5] R.A. Varin, T. Czujko, Z.S. Wronski, Nanomaterials for Solid State Hydrogen Storage, Springer, New York 2009.

[6] M. Balcerzak, M. Jurczyk, Inżynieria materiałowa 5, 370 (2012) (in Polish).

[7] B. Luan, N. Cui, H.K. Liu, H.J. Zhao, S.X. Dou, J. Power Sources 55, 197 (1995).

[8] B. Luan, N. Cui, H.K. Liu, H.J. Zhao, S.X. Dou, Int. J. Hydrogen Energ. 21, 373 (1996).

[9] H.T. Takeshita, N. Kuriyama, T. Sakai, I. Uehara, M. Haruta, H. Tanaka, J. Alloys Comp. 311, 188 (2000).

[10] H.T. Takeshita, H. Tanaka, T. Kiyobayashi, N. Takeichi, N. Kuriyama, J. Alloys Comp. 330, 517 (2002).

[11] B. Huang, P. Shi, C. Lu, Z. Liang, M. Chen, Rare Metal Mater. Eng. 34, 557 (2005).

[12] R.J. Shih, Y.O. Su, T.P. Perng, J. Alloys Comp. 353, 283 (2003).

[13] M. Balcerzak, M. Nowak, J. Jakubowicz, M. Jurczyk, Renew. Energ. 62, 432 (2014). 